\title{
Analisis Hukum Mengenai Tindak Pidana Anak Yang Terlibat Geng Motor Sebagai Upaya Penegakan Hukum
}

\section{Legal Analysis Regarding the Crime of Children Involved in Motorcycle Gangs as Law Enforcement Efforts}

\author{
Kaston Rudy Samosir'1), Ediwarman ${ }^{2)}$ \& Taufik Siregar*1) \\ 1)Program Studi Magister Ilmu Hukum, Universitas Medan Area, Indonesia \\ 2)Universitas Sumatera Utara, Indonesia \\ Diterima: 18 Juni 2021; Direview: 31 Juli 2021; Disetujui: 30 September 2021 \\ *Coresponding Email: taufiksiregar@staff.uma.ac.id
}

\begin{abstract}
Abstrak
Artikel atau tulisan ini bertujuan untuk mengkaji dan menganalisis aturan hukum yang mengatur tentang anak yang terlibat Geng Motor, serta faktor penyebab terjadinya tindak pidana terhadap anak yang terlibat Geng Motor, serta kebijakan hukum yang dilakukan oleh pihak Kepolisian terhadap Anak yang terlibat Geng Motor. Masalah difokuskan pada bagaimana aturan hukum yang mengatur tentang anak yang terlibat Geng Motor. Guna mendekati masalah ini dipergunakan acuan teori penegakan hukum, teori kepastian hukum dan teori kebijakan. Metode penelitian dalam penulisan ini adalah metode penelitian hukum normatif. Data-data dikumpulkan melalui sumber data primer, sekunder dan tersier, selanjutnya dianalisis dengan mempergunakan metode analisis kualitatif. Kajian ini menyimpulkan bahwa Aturan hukum mengenai anak yang terlibat geng motor tedapat dalam: Undang-Undang Dasar Negara Republik Indonesia Tahun 1945, Undang-Undang Nomor 1 Tahun 1946 tentang KUHP, Undang-Undang Nomor 1 Tahun 1974 tentang Perkawinan, Undang-Undang Nomor 4 Tahun 1979 tentang Kesejahteraan Anak, Undang-Undang Nomor 3 Tahun 1997 tentang Pengadilan Anak, Undang-Undang Nomor 23 Tahun 2002 tentang Perlindungan Anak, Undang-Undang Nomor Nomor 35 Tahun 2014 tentang Perubahan Atas UndangUndang Nomor 23 Tahun 2002 tentang Perlindungan Anak, Undang-Undang Nomor 11 Tahun 2012 tentang Sistem Peradilan Pidana Anak, Faktor Penyebab Terjadinya Tindak Pidana Terhadap Anak Yang Terlibat Geng Motor adalah sebagai berikut: (1) Faktor keluarga, (2) Faktor lingkungan pergaulan, (3) Faktor pendidikan. Kebijakan Hukum Yang Dilakukan Oleh Pihak Kepolisian Terhadap Anak Yang Terlibat Geng Motor adalah sebagai berikut: (1) Kebijakan penal yang dilakukan terhadap anak yang terlibat geng motor serta melakukan kebijakan non penal.
\end{abstract}

Kata Kunci: Analisis Hokum; Tindak Pidana; Geng Motor; Penegakan Hukum.

\begin{abstract}
This article or article aims to examine and analyze the legal rules governing children involved in motorcycle gangs, as well as the factors causing criminal acts against children involved in motorcycle gangs, as well as legal policies carried out by the police against children involved in motorcycle gangs. The problem is focused on how the legal rules regulate children who are involved in motorcycle gangs. In order to approach this problem, the reference theory of law enforcement, theory of legal certainty and theory of policy is used. The research method in this paper is a normative legal research method. The data were collected through primary, secondary and tertiary data sources, then analyzed using qualitative analysis methods. This study concludes that the legal rules regarding children involved in motorcycle gangs are contained in: the 1945 Constitution of the Republic of Indonesia, Law Number 1 of 1946 concerning the Criminal Code, Law Number 1 of 1974 concerning Marriage, Law Number 41979 concerning Child Welfare, Law Number 3 of 1997 concerning Juvenile Court, Law Number 23 of 2002 concerning Child Protection, Law Number 35 of 2014 concerning Amendments to Law Number 23 of 2002 concerning Child Protection, Law Number 11 of 2012 concerning the Juvenile Criminal Justice System. Factors that cause crime against children involved in motorcycle gangs are as follows: (1) family factors, (2) social environment factors, (3) education factors. The legal policies carried out by the police against children involved in motorcycle gangs are as follows: (1) Penal policies are applied to children involved in motorcycle gangs as well as non-penal policies.
\end{abstract}

Keywords: Legal Analysis; Crime; Motorcycle Gangs; Law Enforcement.

How to Cite: Samosir, K.R. Ediwarman. \& Siregar, T. (2021). Analisis Hukum Mengenai Tindak Pidana Anak Yang Terlibat Geng Motor Sebagai Upaya Penegakan Hukum. Journal of Education, Humaniora and Social Sciences (JEHSS). 4 (2): 1113-1121 


\section{PENDAHULUAN}

Pembicaraan tentang anak dan perlindungannya tidak akan pernah berhenti sepanjang sejarah kehidupan, karena anak adalah generasi penerus bangsa dan penerus pembangunan, yaitu generasi yang dipersiapkan sebagai subjek pelaksana pembangunan yang berkelanjutan dan pemegang kendali massa depan suatu negara, tidak terkecuali indonesia. Perlindungan anak Indonesia berarti melindungi potensi sumber daya insani dan membangun manusia Indonesia seutuhnya, menuju masyarakat yang adil dan makmur, materil spiritual berdasarkan Pancasila dan UUD 1945. (Nashriana, 2018).

Perlindungan terhadap anak, merupakan hak asasi yang harus diperoleh anak. Sehubungan dengan hal ini, Pasal 27 ayat (1) UUD 1945, menentukan bahwa setiap warga negara bersamaan kedudukannya di dalam hukum dan pemerintahan dan wajib menjunjung hukum dan pemerintahan itu dengan tidak ada kecualinya. Pernyataan dari pasal tersebut, menunjukkan tidak ada perbedaan kedudukan di dalam hukum dan pemerintahan bagi semua warga negara, baik wanita, pria, dewasa dan anak-anak dalam mendapat perlindungan hukum. Masalah perlindungan hukum terhadap anak, bukan saja masalah hak asasi manusia, tetapi lebih luas lagi adalah masalah penegakan hukum, khususnya penegakan hukum terhadap anak sebagai korban tindak kekerasan (Maidin, 2019).

Inilah mengapa, setiap tindakan anak, sejatinya tidak selalu merefleksikan realitas diri, namun justru lebih condong kepada pola replikasi atas hasil tangkapan panca indera keseharian (Muhammad, 2017). Anak adalah bagian warga Negara yang harus dilindungi karena mereka merupakan generasi bangsa yang di masa mendatang akan melanjutkan kepemimpinan bangsa Indonesia. Setiap Anak disamping wajib mendapatkan pendidikan formal seperti sekolah, juga wajib mendapatkan pendidikan moral sehingga mereka dapat tumbuh menjadi sosok yang berguna bagi bangsa dan negara (Dahlan, 2017). Anak yang kurang atau tidak memperoleh perhatian secara fisik, mental maupun sosial sering berperilaku dan bertindak asosial dan bahkan antisosial yang merugikan dirinya, keluarga, dan masyarakat. (Bambang, 2019)

Seseorang melakukan perilaku yang terlarang karena hati nurani, atau superego-nya begitu lemah atau tidak sempurna sehingga ego-nya (yang berperan sebagai suatu penengah atau superego dan $i d$ ) tidak mampu mengontrol dorongan-dorongan dari id (bagian dari kepribadian yang mengandung keinginan dan dorongan yang kuat untuk dipuaskan dan dipenuhi) (Topo, 2001).

Para remaja berada dalam kondisi kebingungan terutama dalam memilih cara dan jalan hidup masing-masing yang sedikit banyaknya dipengaruhi oleh orang tua dan lingkungan. Dua faktor inilah yang memberikan keputusan dan penapsiran akan persepsi mereka terhadap dunia (world of views) (Purwanto, 1990)

Geng motor adalah kumpulan orang-orang pencinta motor yang suka kebut-kebutan, tanpa membedakan jenis motor yang dikendarai. Berbeda dengan itu, Club Motor adalah kelompok yang mengusung merek kendaraan motor tertentu atau spesifikasi jenis motor tertentu dengan perangkat organisasi formal, seperti HDC (Harley Davidson Club) , Scooter (kelompok pecinta vesva), kelompok Honda, kelompok Suzuki, Tiger, Mio. Ada juga brotherhood kelompok pecinta motor besar tua. Tapi kalau soal aksi jalanan, semuanya sama saja, kebanyakan sama-sama merasa jadi raja jalanan, tidak mau didahului, apalagi disalip oleh pengendara lain (Ilham, 2012).

Tindak pidana yang dilakukan oleh anak bisa disebabkan oleh kemiskinan (faktor ekonomi), pemaksaan yang dilakukan oleh orang dewasa terhadap anak, pengaruh lingkungan atau masalah di dalam keluarga sehingga anak menjadi korban. Untuk itu pendampingan terhadap anak tidak hanya pada anak yang menjadi korban kekerasan tapi juga meliputi anak yang berhadapan dengan hokum (Yasin, 2014).

Tindakan remaja ini merupakan suatu perbuatan amoral. Sebagai generasi penerus bangsa, harusnya anak-anak ini belajar menuntut ilmu di sekolah bukan melakukan keonaran. Untuk itu, perlu bagi masyarakat untuk menanggulangi tindakan kenakalan remaja ini, terutama sekolahsekolah yang sebagai tempat menuntut ilmu harusnya bisa mendidik anak-anak sehingga kelak mereka menjadi anak yang berguna bagi nusa dan bangsanya (Asmara, S., \& Ridho, H., 2018) 
Teori yang digunakan dalam penelitian ini adalah: (1). Teori Penegakan Hukum Membahas mengenai teori-teori penegakan hukum sesungguhnya terdapat berbagai teori yang berkenaan dengan hal-hal yang mempengaruhi penegakan hukum positif di Indonesia (Rudi, 2016). (2) Teori Kepastian Hukum: Kepastian hukum merupakan sebuah jaminan bahwa hukum tersebut harus dijalankan dengan cara yang baik. Kepastian hukum menghendaki adanya upaya pengaturan hukum dalam perundang-undangan yang dibuat oleh pihak yang berwenang dan berwibawa, sehingga aturan-aturan itu memiliki aspek yuridis yang dapat menjamin adanya kepastian bahwa hukum berfungsi sebagai suatu peraturan yang harus ditaati. (Soeroso, 2011). (3) Teori Kebijakan: Secara terminology kebijakan berasal dari istilah "policy" (Inggris) atau "politiek" (Belanda). Terminologi tersebut dapat diartikan sebagai prinsip-prinsip umum yang berfungsi untuk mengarahkan pemerintah (termasuk penegak hukum) dalam mengelola, mengatur atau menyelesaikan urusan-urusan publik, masalah-masalah masyarakat atau bidang-bidang penyusunan peraturan perundang-undangan dan mengalokasikan hukum/peraturan dalam suatu tujuan (umum) yang mengarah pada upaya mewujudkan kesejahtraan dan kemakmuran masyarakat (Warga Negara).

Tujuan dari penelitian ini adalah untuk mengkaji bagaimana aturan hukum yang mengatur tentang anak yang terlibat Geng Motor, serta bagaimana faktor penyebab terjadinya tindak pidana terhadap anak yang terlibat Geng Motor. Dan dilihat bagaimana kebijakan hukum yang dilakukan oleh pihak Kepolisian terhadap Anak yang terlibat Geng Motor

\section{METODE PENELITIAN}

Pendekatan-pendekatan yang Penelitian ini mengambil lokasi di Kota Medan yang bertempat di Polrestabes medan, pertimbangan mengenai dipilihnya lokasi penelitian ini yaitu dengan melakukan penelitian di Polrestabes Medan penulis dapat memperoleh data yang lengkap, akurat dan memadai mengenai Tindak Pidana Anak yang Terlibat Geng Motor. Penelitian Tesis ini menggunakan penelitian hukum Normatif, yaitu penelitian yang mengacu kepada norma-norma hukum yang terdapat dalam peraturan perundang-undangan yang berlaku sebagai pijakan normatif. (Amiruddin, 2006).

Penelitian hukum normatif adalah penelitian yang dilakukan dengan cara meneliti bahan pustaka (data sekunder) atau penelitian hukum perpustakaan. Diperlukan metode-metode tertentu sehingga terhadap suatu peristiwa hukum dapat ditetapkan bagaimana hukumnya, Jika metode pendekatan yang dipergunakan dalam penelitian adalah metode pendekatan normatif, yang secara deduktif, dimulai analisis terhadap pasal-pasal yang mengatur hal-hal yang menjadi permasalahan di atas, metode pendekatan ini digunakan dengan mengingat permasalahan yang diteliti berdasarkan pada peraturan-peraturan perundang-undangan yaitu hubungan peraturan satu dengan peraturan lain serta kaitannya dengan penerapannya dalam praktek. (Ediwarman, 2015).

Prosedur pengambilan data dan pengumpulan data peneliti harus mengusahakan sebanyak mungkin data yang diperoleh atau dikumpulkan mengenai masalah-masalah yang berhubungan dengan peneliti, disini peneliti mempergunakan data primer dan sekunder data yang diperoleh dengan cara studi kepustakaan dan studi lapangan. Setelah bahan hukum terkumpul kemudian dilakukan analisis untuk mendapatkan argumentasi akhir yang berupa jawaban terhadap permasalahan penelitian. Terdapat beberapa jenis teknik analisis data, tetapi dalam penelitian ini penulis menggunakan teknik analisis data secara kualitatif

\section{DAN PEMBAHASAN}

\section{Aturan Hukum Yang Mengatur Tentang Anak Yang Terlibat Geng Motor}

Di dalam ketentuan Pasal 28 B ayat (2) Undang-Undang Dasar 1945 ditegaskan bahwa: "Setiap anak berhak atas kelangsungan hidup, tumbuh dan berkembang serta berhak atas perlindungan dari kekerasan dan diskriminasi“, Ketentuan tersebut telah memberikan landasan yang kuat bahwa anak berhak untuk hidup, tumbuh dan berkembang serta berhak untuk memperoleh perlindungan dari kekerasan, eksploitasi dan diskriminasi. Perlindungan anak juga ditegaskan dalam Undang-Undang Dasar Tahun 1945 yaitu Pasal 28 D ayat (1) Undang-Undang 
Dasar 1945 "setiap orang berhak atas pengakuan, jaminan, perlindungan dan kepastian hukum yang adil serta perlakuan yang sama di hadapan hukum (Sudrajat, 2011).

Dalam Kitab Undang Hukum Pidana memang tidak secara tegas mengatur tentang batasan seorang dikatakan dewasa atau masih kategori anak. Akan tetapi dapat kita lihat pada Pasal 45, Pasal 46 dan Pasal 47 tentang pengaturan seseorang yang melakukan tindak pidana dan belum mencapai umur 16 (enam belas) tahun mendapat pengurangan ancaman hukuman dibanding orang dewasa. Hilman Hadikusuma menyatakan bahwa batas antara belum dewasa dengan yang sudah dewasa sebenarnya tidak perlu dipermasalahkan. Hal ini disebabkan pada kenyataannya walaupun belum dewasa, anak-anak dapat melakukan perbuatan hukum. Misalnya, telah melakukan jual beli, berdagang, dan sebagainya (harrys, 2020)

Pasal 50 Ayat (1) menyebutkan anak yang belum mencapai umur 18 (delapan belas) tahun atau belum pernah melangsungkan perkawinan, yang tidak berada di bawah kekuasaan orang tua, berada di bawah kekuasaan wali. Sedangkan mengenai batasan usia untuk melangsungkan perkawinan ditentukan dalam Pasal 6 Ayat (2) yaitu untuk melangsungkan perkawinan seorang yang belum mencapai umur 21 (dua puluh satu) tahun harus mendapat izin kedua orang tua. Pasal 7 Ayat (1) memuat batas umur minimum bagi seseorang yang akan melangsungkan perkawinan, yaitu perkawinan hanya dapat diizinkan jika pihak pria mencapai umur 19 (sembilan belas) tahun dan pihak wanita sudah mencapai umur 16 (enam belas) tahun.

Batas usia anak dirumuskan dalam Pasal 1 Angka dua yaitu anak adalah seseorang yang belum mencapai usia 21 (dua puluh satu) tahun dan belum pernah kawin. Menurut UndangUndang ini, batas usia 21 tahun ditetapkan berdasarkan pertimbangan kepentingan usaha kesejahteraan sosial, tahap kematangan sosial, tahap kematangan pribadi dan tahap kematangan mental. Pada usia 21 tahun, anak sudah dianggap mempunyai kematangan sosial, kematangan pribadi dan kematangan mental.

Selanjutnya dijelaskan pula bahwa: batas umur 21 tahun tidak mengurangi ketentuan batas dalam peraturan perundang-undangan lainnya, dan tidak pula mengurangi kemungkinan anak melakukan perbuatan sejauh ia mempunyai kemampuan untuk itu berdasarkan hukum yang berlaku (Liza, 2016).

Orang tua seharusnya memperhatikan pemenuhan kebutuhan hak anak, pendidikan yang benar dan suasana yang kondusif terhadap pertumbuhan dan perkembangan anak. Tanggung jawab orang tua terhadap anaknya adalah mencukupi kebutuhannya baik fisik maupun psikis. Lingkungan yang baik juga akan menentukan perilaku anak di kehidupan selanjutnya.

Pembicaraan tentang anak dan perlindungannya tidak akan pernah berhenti sepanjang sejarah kehidupan, karena anak adalah generasi penerus bangsa dan penerus pembangunan, yaitu generasi yang dipersiapkan sebagai subjek pelaksanaan pembangunan yang berkelanjutan dan pemegang kendali masa depan suatu negara, tidak terkecuali Indonesia. Perlindungan anak Indonesia berarti melindungi potensi sumber daya insani dan membangun manusia Indonesia seutuhnya, menuju masyarakat yang adil dan makmur, materil spiritual berdasarkan Pancasila dan UUD 1945.

Di dalam Undang-Undang Nomor 23 Tahun 2002 tentang Perlindungan Anak disebutkan anak adalah seseorang yang belum berusia 18 (delapan belas) tahun, termasuk anak yang masih dalam kandungan (Pasal 1 ayat 1). Pasal ini mengadopsi KHA, yang menyebutkan anak adalah setiap manusia yang berusia di bawah 18 tahun kecuali, berdasarkan Undang-Undang yang berlaku bagi anak-anak, kedewasaan dicapai lebih cepat (pasal 1) (Nashriana, 2018).

Negara, Pemerintah, Pemerintah Daerah, Masyarakat, Keluarga dan Orang Tua berkewajiban untuk memberikan perlindungan dan menjamin terpenuhinya Hak asasi anak sesuai dengan tugas dan tanggungjawabnya. Perlindungan terhadap anak yang dilakukan selama ini belum memberikan jaminan bagi anak untuk mendapatkan perlakuan dan kesempatan yang sesuai dengan kebutuhannya dalam berbagai bidang kehidupan, sehingga dalam melaksanakan upaya perlindungan terhadap Hak anak oleh Pemerintah harus didasarkan pada prinsip hak asasi manusia yaitu penghormatan, pemenuhan, dan perlindungan atas hak anak (Rizkan, 2020). 


\section{Faktor Penyebab Terjadinya Tindak Pidana Terhadap Anak Yang Terlibat Geng Motor}

Suatu perbuatan itu disebut delikuen apabila perbuatan-perbuatan tersebut bertentangan dengan norma-norma yang ada pada masyarakat di mana ia hidup, suatu perbuatan yang anti sosial di mana di dalamnya terkandung unsur-unsur anti normatif. Juvenile delinkquency (kenakalan remaja) bukan hanya merupakan perbuatan anak yang melawan hukum semata akan tetapi juga termasuk di dalamnya perbuatan yang melanggar norma masyarakat. Dewasa ini sering terjadi seorang anak digolongkan sebagai delikuen jika pada anak tersebut nampak adanya kecenderungan-kecenderungan anti sosial yang sangat memuncak sehingga perbuatan-perbuatan tersebut menimbulkan gangguan-gangguan terhadap keamanan, ketenteraman dan ketertiban masyarakat, misalnya pencurian, pembunuhan, penganiayaan, pemerasan, penipuan, penggelapan dan gelandangan serta perbuatan-perbuatan lain yang dilakukan oleh anak remaja yang meresahkan masyarakat (Sudarsono, 2012).

Faktor penyebab terjadinya tindak pidana terhadap anak yang terlibat Geng Motor: Kenakalan remaja yang sering terjadi di dalam masyarakat bukanlah suatu keadaan yang berdiri sendiri. Kenakalan remaja tersebut timbul karena adanya beberapa sebab dan tiap-tiap sebab dapat ditanggulangi dengan cara-cara tertentu. Faktor Eksternal penyebab anak terlibat geng motor adalah sebagai berikut: (a) Keluarga Sebagai Penyebab Kenakalan Remaja dan Peranan Kontrol di Dalamnya. (b) Faktor Lingkungan Pergaulan. (c) Faktor Pendidikan.

Faktor Internal Penyebab Terjadinya Tindak Pidana Anak Yang Terlibat Geng Motor: Faktor internal berupa ketidakmampuan remaja dalam melakukan penyesuaian sosial atau beradaptasi terhadap nilai dan norma yang ada di dalam masyarakat. Hal tersebut menunjukkan ketidakmampuan remaja-remaja tersebut dalam berperilaku adaptif, mereka memiliki kemampuan penyesuaian sosial serta kemampuan menyelesaikan masalah yang rendah, sikap. (a) Krisis identitas; (b) Kontrol diri yang lemah. Banyak faktor penyebab remaja terjerumus ke dalam kawanan geng motor. Namun, salah satu penyebab utama mengapa remaja memilih bergabung dengan geng motor adalah kurangnya perhatian dan kasih sayang orang tua. Mencuatnya perilaku negatif anak remaja yang masuk dalam kelompok atau geng motor, dapat disebabkan oleh beberapa hal: yakni faktor internal dan faktor eksternal. Dari faktor internal: pertama, anak geng tersebut memiliki kepribadian mengontrol diri yang lemah. Sehingga mereka tidak bisa mengendalikan dan mengerem perilaku yang dianggap tidak baik dan merugikan masyarakat. Kedua, anak yang bersangkutan gagal untuk mengaktualisasikan dirinya. Mereka tidak mampu untuk menunjukkan eksistensi yang positif, yang muncul, malahan ulah yang negatif. Kegagalan ini menunjukkan kelemahannya dalam menentukan mana perilaku yang baik dan mana yang tidak baik. Faktor lain yang mendorong remaja bergabung dengan geng motor dipengaruhi oleh kondisikondisi sosiologis. Contoh paling mudah ditemui yakni lingkungan keluarga dan lingkungan sosial yang gagal dalam memberikan perlindungan psikologis dan kontrol sosial.

Berdasarkan hasil wawancara dengan Ipda Rudianto selaku Penyidik di Polrestabes Medan bahwa tingkat pendidikan anggota geng motor yang terlibat dalam aksi kejahatan di Kota Medan cukup beragam. Sekolah Menegah Pertama adalah yang paling banyak tergabung dan terlibat dalam aksi kejahatan yang dilakukan oleh geng motor. Banyaknya remaja yang tergabung dalam geng motor dan terlibat dalam aksi kejahatan disebabkan karena usia remaja yang masih labil dan suka meniru atau mengikuti teman sebaya atau orang yang usianya telah dewasa.

Faktor Internal Penyebab Terjadinya Tindak Pidana Anak Yang Terlibat Geng Motor: Ketika membahas masalah kenakalan atau tindakan kriminal yang dilakukan oleh anak, hal yang ingin diketahui adalah apa yang melatarbelakangi atau faktor yang menyebabkan anak melakukan tindakan kriminal. Faktor internal yang mempengaruhi perilaku kenakalan oleh anak, merupakan aspek kepribadian yang berasal dari dalam diri anak seperti konsep diri yang rendah, penyesuaian sosial serta kemampuan menyelesaikan masalah yang rendah, sikap yang berlebihan serta pengendalian diri yang rendah. Konsep diri adalah bagaimana individu memandang dirinya sendiri meliputi aspek fisik dan aspek psikologis. Aspek fisik adalah bagaimana individu memandang kondisi tubuh dan penampilannya sendiri. Sedangkan aspek psikologi adalah bagaimana individu tersebut memandang kemampuan-kemampuan dirinya, harga diri serta rasa percaya diri dari individu tersebut. Dalam sebuah penelitian yang dilakukan di Kendal ditemukan 
bahwa yang menjadi faktor penyebab yang dominan dari siswa-siswa melakukan kenakalan adalah faktor sifat dari remaja itu sendiri

Peran Penegak Hukum Sebagai Pencegah Dan Mengatasi Anak Yang Terlibat Geng Motor : Di antara pekerjaan penegakan hukum dalam Sistem Peradilan Pidana di Indonesia, yang terdiri dari Kepolisian, Kejaksaan, Pengadilan, Pengacara dan Lembaga Pemasyarakatan, maka pekerjaan kepolisian adalah yang paling menarik, karena di dalamnya banyak keterlibatan manusia dalam pengambilan keputusan. Polisi pada hakikatnya sebagai hukum yang hidup, karena di tangan polisi tersebut hukum mengalami perwujudannya, terutama di bidang pidana. Apabila hukum bertujuan untuk menciptakan ketertiban dalam masyarakat dengan melawan kejahatan. Akhirnya polisi akan menertibkan secara konkret apa yang disebut sebagai penegak ketertiban.

Menurut Pasal 13 Undang-Undang Nomor 2 Tahun 2002, tentang Kepolisian Negara Republik Indonesia, ada 3 tugas pokok POLRI yaitu: (1) Memelihara keamanan dan ketertiban masyarakat. (2) Menegakkan hokum, (3) Memberi perlindungan, pengayoman dan pelayanan kepada masyarakat.

Tugas POLRI dalam mewujudkan penegakan hukum guna terpeliharanya keamanan dan ketertiban pada hakikatnya dapat dilihat sebagai hukum yang hidup (living law), karena di tangan POLRI itulah hukum menjadi konkret atau mengalami perwujudannya di dalam masyarakat. Pada polisi ini, POLRI diharapkan dapat berbuat banyak untuk berperan dalam penegakan hukum (law enforcement) dari masyarakat yang dilayaninya. Penegakan hukum (Law enforcement) yaitu sebagai suatu usaha untuk mengekspresikan citra moral yang terkandung di dalam hukum. Citra moral yang terkandung di dalam hukum bisa ditegakkan melalui aparat penegak hukum. Dilihat dari aspek normatif tugas POLRI sebagai aparat penegak hukum, diatur dalam Undang-Undang Nomor 2 Tahun 2002 tentang Kepolisian Negara Republik Indonesia dan Undang-Undang Nomor 8 tahun 1981 tentang Hukum Acara Pidana. Di samping itu tugas POLRI sebagai penegak hukum, POLRI juga mempunyai tugas memelihara keamanan dan ketertiban masyarakat, memberikan pertimbangan, pengayoman dan pelayanan kepada masyarakat (Adi, 2018). (Purnama Adi 2018).

\section{Kebijakan Hukum Yang Dilakukan Oleh Pihak Kepolisian Terhadap Anak Yang Terlibat Geng Motor}

\section{A. Kebijakan Penal Terhadap Anak Yang Terlibat Geng Motor}

Upaya atau kebijakan untuk melakukan pencegahan dan penanggulangan kejahatan termasuk bidang kebijakan kriminal (criminal policy). Kebijakan kriminal ini pun tidak terlepas dari kebijakan yang lebih luas, yaitu kebijakan sosial (social policy) yang terdiri dari upaya/kebijakan untuk kesejahteraan sosial (social welfare policy) dan kebijakan untuk perlindungan masyarakat (social defence policy). Dengan demikian sekiranya kebijakan penanggulangan kejahatan (politik kriminal) dilakukan dengan menggunakan sarana penal (hukuman) maka kebijakan hukum pidana (penal policy) khususnya dalam kebijakan yudikatif/aplikatif (penegakan hukum pidana in concerto) harus memerhatikan dengan mengarah pada tercapainya tujuan dan kebijakan sosial itu, berupa social welfare dan social defence (Hatta, 2010).

Salah satu aspek penting yang harus diperhatikan dalam perjalanan hidup seorang remaja adalah pembentukan identitasnya. Aspek ini merupakan titik paling krisis bagi setiap remaja karena pada masa remaja, mereka justru sedang bingung dan ragu-ragu menentukan identitasnya. Dunia remaja adalah dunia yang unik dan penuh dengan rasa ingin tahu. Hal yang tidak boleh diabaikan adalah bahwa kenakalan anak/remaja tidaklah berdiri sendiri dan terjadi secara tibatiba. Melainkan melalui proses. Didalam proses tersebut banuak unsur yang terlibat mempengaruhi kualitas mereka dalam melakukan kenakalan.

Suatu kebijakan yang rasional untuk menanggulangi kejahatan disebut dengan politik kriminal. Kebijakan kriminal bila dilihat lingkupnya, sangat luas dan tinggi kompleksitasnya. Pada hakikatnya kejahatan merupakan masalah kemanusiaan dan sekaligus masalah sosial yang memerlukan pemahaman tersendiri. Kejahatan sebagai masalah soaial merupakan gejala yang dinamis, selalu tumbuh dan terkait dengan gejala dan struktur kemasyarakatan lainnya yang sangat kompleks, yang merupakan suatu socio political problems.

1 htm: ht://mahesainstitute.web.id/ojs2/index.php/jehss mahesainstitut@gmail.com

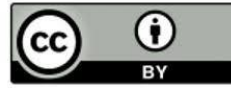

This work is licensed under a Creative Commons Attribution 4.0 
Dalam upaya pencegahan (represif) tindak pidana kejahatan yang dilakukan kelompok geng motor di kota Medan, maka upaya penal yang dilakukan pihak Kepolisian Resor Kota Medan adalah sebagai berikut: (1) Melakukan Kontrol di setiap persimpangan jalan yang sering terjadi bentrok antar geng motor; (2) Melaksanakan Kontrol dengan menggunakan CCTV yang terdapat di setiap sudut jalan yang sering terjadi bentrokan antar geng motor; (3) Melaksanakan razia ke antar sekolah yang rawan siswanya bergabung dengan geng motor. (4) Melaksanakan Razia rutin. (5) Melakukan patroli. (6) Melakukan pembubaran jika terdapat siswa yang berkerumun. (7) Melakukan pembubaran terhadap geng motor yang akan melakukan balapan liar. Kebijakan yang dilakukan pihak Polrestabes Medan dalam hal mencegah kejahatan yang dilakukan oleh geng motor tersebut diatas adalah dengan melakukan pencegahan yaitu : (1) Melakukan Patroli; (2) Melakukan penertiban terhadap kelompok yang melakukan balap liar; (3) Melakukan Razia ke sekolah-sekolah terhadap sepeda motor yang tidak memiliki spesifikasi standar; (4) Melakukan penjagaan di simpang jalan yang rawan terjadi tempat berkumpulnya para geng motor. Upaya Penal yang dilakukan oleh Polrestabes Medan adalah dengan menerapkan Pasal-pasal yang berkenaan dengan KUHP dan Peraturan Perundang-undangan yang berlaku. Tugas polisi dalam hal ini dimulai dengan adanya laporan dari masyarakat yang merasa resah dengan adanya tindakan-tindakan yang dilakukan oleh geng motor. Setelah mendengar dan menerima laporan tersebut, beberapa anggota polisi segera turun untuk melakukan penyelidikan.

Dalam melakukan penyelidikan, polisi segera terjun ke lokasi kejadian untuk mencari tahu apakah laporan masyarakat yang menyatakan bahwa telah terjadi perbuatan yang meresahkan warga yang dilakukan oleh geng motor itu benar atau tidak. Apabila setelah melakukan pengecekan dan pengintaian beberapa saat di lokasi kejadian memang benar telah terjadi tindak pidana yang dilakukan oleh geng motor, maka selanjutnya polisi melakukan penangkapan terhadap para remaja dan kemudian mengumpulkan barang bukti serta para saksi. Dengan demikian dapat diterima bahwa upaya penanggulangan masalah kejahatan tiada lain adalah membahas masalah reaksi masyarakat terhadap masalah kejahatan. Walaupun banyak variasi dari reaksi masyarakat, namun untuk sementara variasi-variasi tersebut berkisar di antara reaksireaksi yang bersifat pinitip, dan reaksi yang bersifat perlakuan (treatment). Salah satu reaksi masyarakat yang bersifat punitip dan diakui oleh negara-negara modern adalah dalam bentuk Hukuman (punishment) (Nandang, 2019).

\section{B. Kebijakan Non Penal Terhadap Anak Yang Terlibat Geng Motor}

Penanggulangan kejahatan yang telah diungkapkan oleh G.P Hoefnagels secara garis besar dapat dikelompokan menjadi dua bagian, yaitu penanggulangan kejahatan secara penal dan penanggulangan kejahatan secara non penal. Penal policy merupakan bentuk penanggulangan kejahatan yang menitikberatkan pada pada tindakan represif setelah terjadinya suatu tindak pidana, sedangkan non penal policy lebih menekankan tindakan preventif sebelum terjadinya suatu tindak pidana (Hasmayni, 2016).

Menurut pandangan politik kriminal non penal policy merupakan kebijakan penanggulangan kejahatan yang paling strategis. Karena bersifat pencegahan sebelum terjadinya tindak pidana. Sarana non penal adalah menangani dan menghapuskan faktor-faktor kondusif yang menyebabkan terjadinya suatu tindak pidana. Mengingat upaya penanggulangan kejahatan lewat jalur non penal lebih bersifat tindakan pencegahan untuk terjadinya kejahatan, maka sasaran utamanya adalah menangani faktor-faktor kondusif penyebab terjadinya kejahatan.

Faktor-faktor kondusif itu antara lain, berpusat pada masalah-masalah atau kondisi-kondisi sosial yang secara langsung atau tidak langsung dapat menimbulkan kejahatan. Dengan demikian, dilihat dari sudut politik kriminal secara makro dan global, maka upaya-upaya non penal menduduki posisi kunci dan strategis dari keseluruhan upaya politik criminal (Sitorus, Dkk, 2020).

Di berbagai Kongres PBB mengenai "The Prevention of Crime and Treatment of Offenders" ditegaskan upaya-upaya strategis mengenai penanggulangan sebab-sebab timbulnya kejahatan upaya non penal yang paling strategis adalah segala upaya untuk menjadikan masyarakat sebagai lingkungan sosial dan lingkungan hidup yang sehat dari faktor-faktor yang menyebabkan terjadinya suatu kejahatan. Ini berarti, masyarakat dengan seluruh potensinya harus dijadikan 赵 $h t t p: / / m a h e s a i n s t i t u t e . w e b . i d / o j s 2 /$ index.php/jehss 
sebagai faktor penangkal kejahatan yang merupakan bagian integral dari keseluruhan politik criminal.

Menurut Soedjono Dirdjosisworo, dalam usaha penanggulangan kejahatan cara umum yang konsepsional, dilakukan dengan memadukan berbagai unsur yang berhubungan dengan mekanisme peradilan pidana serta partisipasi masyarakat, yang dapat dijelaskan sebagai berikut: (a) Peningkatan dan pemantapan aparatur penegak hukum, meliputi pemantapan organisasi, personel dan sarana prasarana untuk penyelesaian perkara pidana. (b) Perundang-undangan yang dapat berfungsi menganalisir dan membendung kejahatan dan mempunyai jangkauan ke masa depan. (c) Mekanisme peradilan pidana yang efektif dengan syarat-syarat cepat, tepat, murah, dan sederhana. (d) Koordinasi antara aparatur penegak hukum dan aparatur pemerintahan lainnya yang berhubungan, untuk meningkatkan daya guna dalam penanggulangan kriminalitas.

\section{SIMPULAN}

Aturan hukum mengenai anak yang terlibat geng motor tedapat dalam: Undang-Undang Dasar Negara Republik Indonesia Tahun 1945, Undang-Undang Nomor 1 Tahun 1946 tentang KUHP, Undang-Undang Nomor 1 Tahun 1974 tentang Perkawinan, Undang-Undang Nomor 4 Tahun 1979 tentang Kesejahteraan Anak, Undang-Undang Nomor 3 Tahun 1997 tentang Pengadilan Anak, Undang-Undang Nomor 23 Tahun 2002 tentang Perlindungan Anak, UndangUndang Nomor Nomor 35 Tahun 2014 tentang Perubahan Atas Undang-Undang Nomor 23 Tahun 2002 tentang Perlindungan Anak, Undang-Undang Nomor 11 Tahun 2012 tentang Sistem Peradilan Pidana Anak.

Faktor Penyebab Terjadinya Tindak Pidana Terhadap Anak Yang Terlibat Geng Motor adalah sebagai berikut: (1) Faktor keluarga, (2) Faktor lingkungan pergaulan, (3) Faktor pendidikan. Kebijakan Hukum Yang Dilakukan Oleh Pihak Kepolisian Terhadap Anak Yang Terlibat Geng Motor adalah sebagai berikut: (1) Kebijakan penal yang dilakukan terhadap anak yang terlibat geng motor serta melakukan kebijakan non penal.

\section{DAFTAR PUSTAKA}

Amiruddin. (2006). Metode Penelitian Hukum. Bandung: P.T Citra Aditya Bakti.

Asmara, S. \& Ridho, H. (2018). Fenomena Geng Motor di Kota Medan: Satu Konstruksi Model Sosio Psikologi Komunikasi. Jurnal Ilmiah Komunikasi Communique, 1(1), 38-44

Bambang, W. (2019). Pidana dan Pemidanaan. Jakarta: Sinar Grafika.

Dahlan, S. (2017). Penegakan Hukum Dengan Pendekatan Diversi. Yogyakarta: Nusa Media.

Ediwarman. (2015). Metodologi Penelitian Hukum, Panduan Penulisan Skripsi, Tesis, dan Disertasi. Medan: PT. Sofmedia.

Harrys, P. (2020). Hukum Pidana dan Perlindungan Anak di Indonesia. Bandung: CV Pustaka Setia.

Hasmayni, B. (2016). Perilaku Agresif pada Anggota Geng Motor Ditinjau dari Tingkat Usia dan Suku di Kota Medan, Jurnal Pendidikan Ilmu-Ilmu Sosial, 8(2).

Hatta. (2010). Kebijakan Politik Kriminal, Penegakan Hukum Dalam Rangka Penanggulangan Kejahatan. Yogyakarta: Pustaka Pelajar.

Ilham, P. (2012). Komunikasi dan Polisi Bias Selebritas, Geng Motor, Ranah Publik, Konvergensi Simbolik, Jakarta: Prisani Cendekia.

Liza, A. (2016). Hukum Perlindungan Anak Panduan Memahami Anak yang Berkonflik dengan Hukum, Yogyakarta: Deepublish.

Maidin, G. (2019). Perlindungan Hukum Terhadap Anak dan Perempuan. Bandung: Refika Aditama.

Muhammad, R. (2017). Pilar-pilar Hukum Progresif. Yogyakarta: Thafa Media.

Nandang, S. (2019). Kriminologi Prespektif Hukum Pidana. Jakarta: Sinar Grafika.

Nashriana. (2018). Perlindungan Hukum Pidana Bagi Anak di Indonesia. Jakarta: PT. Raja Grafindo.

Purwanto, N. (1990). Psikologi Pendidikan. Bandung: Remaja Rosdakarya.

Rudi, P. (2016). Proses Pengembalian Kerugian Negara Akibat Korupsi. Yogyakarta: Genta Publishing.

Sitorus, J., Zulyadi, R. \& Trisna, W. (2020). Perlindungan Hukum Terhadap Korban Tindak Pidana Pencurian Ditinjau Dari Kajian Victimlogi (Studi Putusan No : 20/Pid.B/2017/PN. Mdn). JUNCTO, 2(1) 2020: 41-50

Soeroso. (2011). Pengantar Ilmu Hukum. Jakarta: PT. Sinar Grafika.

1.20 http://mahesainstitute.web.id/ojs2/index.php/jehss mahesainstitut@gmail.com

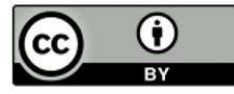

This work is licensed under a Creative Commons Attribution 4.0 
Sudarsono. (2012). Kenakalan Remaja, Prevensi, Rehabilitasi dan Resosialisasi. Jakarta: Rineka Cipta.

Sudrajat, T. (2011). Perlindungan Hukum Terhadap Hak Anak Sebagai Hak Asasi Manusia Dalam Perspektif Sistem Hukum Keluarga Di Indonesia. Kanun Jurnal Ilmu Hukum, 3 (2), 111-132.

Topo, S. (2001). Kriminologi. Jakarta: PT. Raja Grafindo Persada.

Yasin, M. (2014). Panduan Bantuan Hukum di Indonesia. Jakarta: Yayasan Obor Indonesia

Zulyadi, R. (2020). Perlindungan Hukum Terhadap Anak Sebagai Korban Perdagangan Manusia. Medan: C.V Pustaka Prima. 